\title{
PROCESSING AND PROPERTIES OF Nb-Ti-BASED ALLOYS*
}

\author{
Vinod K. Sikka ${ }^{\dagger}$ Srinath Viswanathan, ${ }^{\dagger}$ and Edward A. Loriał \\ $\lceil$ Metals and Ceramics Division, Oak Ridge National Laboratory \\ P.O. Box 2008, Oak Ridge, TN 37831-6083 \\ $\ddagger$ Niobium Products Company, Inc. \\ 300 Corporate Center Drive, Coraopolis, PA 15108
}

\begin{abstract}
The processing characteristics, tensile properties, and oxidation response of two $\mathrm{Nb}-\mathrm{Ti}-\mathrm{Al}-\mathrm{Cr}$ alloys were investigated. One creep test at $650^{\circ} \mathrm{C}$ and $172 \mathrm{MPa}$ was conducted on the base alloy which contained $40 \mathrm{Nb}-40 \mathrm{Ti}-10 \mathrm{Al}-10 \mathrm{Cr}$. A second alloy was modified with 0.11 at. \% carbon and 0.07 at. \% yttrium. Alloys were arc melted in a chamber backfilled with argon, drop cast into a water-cooled copper mold, and cold rolled to obtain a $0.8-\mathrm{mm}$ sheet. The sheet was annealed at $1100^{\circ} \mathrm{C}$ for $0.5 \mathrm{~h}$. Longitudinal tensile specimens and oxidation specimens were obtained for both the base alloy and the modified alloy. Tensile properties were obtained for the base alloy at room temperature, $400,600,700,800,900$, and $1000^{\circ} \mathrm{C}$, and for the modified alloy at room temperature, $400,600,700$, and $800^{\circ} \mathrm{C}$. Oxidation tests on the base alloy and modified alloy, as measured by weight change, were carried out at $600,700,800$, and $900^{\circ} \mathrm{C}$.

Both the base alloy and the modified alloy were extremely ductile and were cold rolled to the final sheet thickness of $0.8 \mathrm{~mm}$ without an intermediate anneal. The modified alloy exhibited some edge cracking during cold rolling. Both alloys recrystallized at the end of a $0.5-\mathrm{h}$ annealing treatment. The alloys exhibited moderate strength and oxidation resistance below $600^{\circ} \mathrm{C}$, similar to the results of alloys reported in the literature. The addition of carbon produced almost no change in either the yield strength or ductility as measured by total elongation. A small increase in the ultimate tensile strength and a corresponding decrease in the reduction of area below $600^{\circ} \mathrm{C}$ were observed. Carbon addition also served to marginally refine the grain size after annealing. The results of this study and those of similar alloys reported in the literature suggest that $40 \mathrm{Nb}-40 \mathrm{Ti}-10 \mathrm{Al}-10 \mathrm{Cr}$ forms a good base alloy suitable for alloying for improvement in its oxidation and high-temperature strength properties.
\end{abstract}

*Research sponsored by the U.S. Department of Energy under contract DE-AC05-84OR21400 with Martin Marietta Energy Systems, Inc.

Superalloys 1992

Edited by S.D. Antolovich, R.W. Stusrud, R.A. MacKay,

D.L. Anton, T. Khan, R.D. Kissinger, D.L. Klarstrom

The Minerals, Metals \& Materials Society, 1992 


\section{$\underline{\text { Introduction }}$}

Niobium alloys represent an attractive alternative to nickel-base alloys for high-temperature material components in jet engines, due to their combination of higher melting point, higher elevated-temperature strength, and lower density, with the potential of increasing service temperatures by several hundred degrees $(1,2)$. Their main drawback is their poor oxidation resistance at temperatures over $600^{\circ} \mathrm{C}(2)$. The use of silicide coatings allows oxidation resistance up to $1400^{\circ} \mathrm{C}(3)$; however, the risk of rapid failure upon the loss of coating integrity remains an important issue in their use (4).

The addition of titanium to niobium alloys improves their oxidation resistance while simultaneously reducing their density (1). The addition of titanium also allows further additions of aluminum and chromium, due to their extensive solid solubility in titanium, resulting in further improvements to oxidation resistance $(1)$. A recent study $(1,2)$ evaluated the tensile properties and oxidation behavior of a series of arc-melted and cast $\mathrm{Nb}-\mathrm{Ti}-\mathrm{Al}-\mathrm{Cr}$ alloys. This study evaluated the mechanical behavior and oxidation response of cold-rolled sheet specimens of an alloy similar to one considered in the previous study. Also, the effect of carbon and yttrium additions to this base alloy was evaluated. The carbon addition was chosen for studying potential strengthening benefits, and the yttrium addition was chosen for studying the possible improvement in oxidation resistance of the base alloy. Table 1 lists the base composition and the extent of carbon and yttrium additions.

Table I. Nominal Chemical Compositions (at. \%) of Alloys Used in This Study

\begin{tabular}{lcccccc}
\hline Heat & Nb & Ti & Al & Cr & C & Y \\
\hline 14610 & 40.21 & 40.34 & 9.55 & 9.91 & -- &.-- \\
14963 & 39.95 & 40.15 & 9.50 & 9.86 & 0.53 & -- \\
14964 & 39.88 & 40.15 & 9.50 & 9.86 & 0.53 & 0.07 \\
$14964 \mathrm{~A}$ & 40.08 & 40.30 & 9.54 & 9.90 & 0.11 & 0.07 \\
\hline
\end{tabular}

\section{Material Processing}

Alloys were prepared by arc melting high-purity materials in a water-cooled copper crucible in a chamber backfilled with argon at $0.07 \mathrm{MPa}$. The buttons were remelted six times to ensure homogeneity, and drop cast into a water-cooled copper mold to form $25 \times 12 \times 75-\mathrm{mm}$ ingots. The ingots were cut into three $25-\mathrm{mm}$ sections. A section from the base alloy ingot and the alloy with 0.11 at. \% C and 0.07 at. \% Y were cold rolled to a final thickness of $0.8 \mathrm{~mm}$. Both sections cold-worked easily from the starting thickness of $25 \mathrm{~mm}$ to the final thickness of $0.8 \mathrm{~mm}$ without any intermediate annealing. However, the alloy with carbon and yttrium exhibited some edge cracking in the final rolled sheet. The alloys with 0.53 at. \% C cracked even after small cold reductions. Further cold rolling after an annealing treatment at $1150^{\circ} \mathrm{C}$ in a $1.6 \times 10^{-4} \mathrm{~Pa}$ vacuum also proved to be unsuccessful. Consequently, sections were first wrapped in molybdenum cover sheets and hot rolled at $900^{\circ} \mathrm{C}$ to obtain a $50 \%$ deformation. Further attempts to cold roll the hot-rolled sheet were also unsuccessful, and further processing was abandoned. This attempt was also unsuccessful, and further processing was abandoned after $50 \%$ hot deformation had been accomplished.

\section{Experimental Procedure}

Longitudinal tensile specimens with a gauge length of $25.4 \mathrm{~mm}$ and pin holes in the grip section were punched from the $0.8-\mathrm{mm}$, as-rolled sheets. $\Lambda$ limited number of tensile specimens with a $12.7-\mathrm{mm}$ gauge were also punched from the base-alloy sheet. Pieces left over after tensile specimens had been punched were used for oxidation tests. Specimens used for oxidation tests were typically 25 by $13 \mathrm{~mm}$ in size. 
The base alloy was tested in three conditions: as-rolled, annealed for $0.5 \mathrm{~h}$ in $1.33 \times 10^{-4} \mathrm{~Pa}$ vacuum at $1100^{\circ} \mathrm{C}$, and annealed for $17 \mathrm{~h}$ in $1.33 \times 10^{-4} \mathrm{~Pa}$ vacuum at $1100^{\circ} \mathrm{C}$. The alloy modified with carbon and yttrium was tested in a single heat-treatment condition, $0.5 \mathrm{~h}$ in $1.33 \times 10^{-4} \mathrm{~Pa}$ vacuum at $1100^{\circ} \mathrm{C}$. In addition, tensile properties were obtained at 400,600 , $700,800,900$, and $1000^{\circ} \mathrm{C}$ for the base alloy in the 0.5 -h vacuum-annealed condition. Elevated-temperature tensile properties were obtained for the modified alloy at 400,600,700 and $800^{\circ} \mathrm{C}$. All tensile tests were conducted in air at a strain rate of $3.33 \times 10^{-3} \mathrm{~s}^{-1}$. One creep test at $650^{\circ} \mathrm{C}$ and $172 \mathrm{MPa}$ was also conducted on the base alloy. Optical micrographs, in both the unetched and etched states, were obtained from the grip section of tensile specimens of the base alloy in the as-rolled and annealed (0.5 and $17 \mathrm{~h}$, respectively) conditions, and the modified alloy in the annealed $(0.5 \mathrm{~h})$ condition, from samples tested at room temperature. An etchant containing 50-ml $\mathrm{HNO}_{3}, 30-\mathrm{g}$ ammonium bi-fluoride $\left(\mathrm{NH}_{4} \mathrm{~F} \cdot \mathrm{HF}\right)$, and $20-\mathrm{ml} \mathrm{H}_{2} \mathrm{O}$ was used. The grain size of the annealed specimens was measured from optical micrographs at $100 \times$ using the line intersection method.

The oxidation response of the base and modified alloys was determined as follows: Oxidation test specimens were measured, weighed, and placed in nickel-aluminide trays. Trays and specimens were placed in furnaces at $600,700,800$, and $900^{\circ} \mathrm{C}$. Specimens were periodically removed and monitored for weight change due to oxidation. Typically, measurements were made every $24 \mathrm{~h}$, except during weekends when measurements were made after $72 \mathrm{~h}$. Oxidation tests were discontinued at the onset of oxide spallation, which occurred at the 800 and $900^{\circ} \mathrm{C}$ test temperatures.

\section{$\underline{\text { Results and Discussion }}$}

The room-temperature tensile properties for the base alloy in three conditions (as-rolled, vacuum-annealed at $1100^{\circ} \mathrm{C}$ for $0.5 \mathrm{~h}$, and vacuum-annealed at $1100^{\circ} \mathrm{C}$ for $17 \mathrm{~h}$ ) are shown in Fig. 1. Figure 2 shows optical metallographs of the alloy for the three conditions illustrated in Fig. 1 and also for the alloy modified with 0.11 at. \% $\mathrm{C}$ and 0.07 at. \% Y after vacuumannealing at $1100^{\circ} \mathrm{C}$ for $0.5 \mathrm{~h}$. The results indicate that the $0.5-\mathrm{h}$ annealing treatment is sufficient to recrystallize the alloys. Grain-size measurements yielded a value of $43 \mu \mathrm{m}$ for the base alloy at the end of the $0.5-\mathrm{h}$ annealing treatment. The 17 - $\mathrm{h}$ annealing treatment resulted in moderate grain growth, with the grain size increasing to $111 \mu \mathrm{m}$. The carbon and yttrium addition to the alloy produced a slight refinement in the grain size, resulting in a value of $39 \mu \mathrm{m}$. Tensile properties for the base alloy correlate well with the microstructure obtained in the particular alloy condition; tensile strengths are highest in the as-rolled condition and lowest in the 17-h anneal condition, where the grain size is comparatively large. Correspondingly, ductility is maximum in the fine-grained, recrystallized condition; both the as-rolled and coarsegrained conditions exhibit low ductility. Optical micrographs of the samples in Fig. 2 in the unetched condition all exhibited finely distributed porosity, presumably retained from the original cast ingots.

Figure 3 shows the variation of tensile properties with temperature. Yield and ultimate tensile strength exhibit a large drop at $400^{\circ} \mathrm{C}$, remain relatively constant between 400 and $800^{\circ} \mathrm{C}$, and decrease again above $800^{\circ} \mathrm{C}$. In Figure 3(a), the yield-strength data reported by Jackson and Jones (1) for a $40 \mathrm{Nb}-40 \mathrm{Ti}-10 \mathrm{Al}-10 \mathrm{Cr}$ alloy have been superimposed on the results for the alloys used in this study. The yield-strength values for the cast material obtained by Jackson and Jones seem to be somewhat higher at temperatures below $800^{\circ} \mathrm{C}$ than the values obtained for the cold-rolled and annealed sheet material used in this study. However, the difference seems to be enhanced due to the lack of any data reported by Jackson and Jones between room temperature and $600^{\circ} \mathrm{C}$. The carbon and yttrium addition, which produces only a minor change in the grain size, has essentially no effect on the yield and ultimate tensile strength of the alloy. Both the base and modified alloy exhibit over $20 \%$ elongation at room temperature in the finegrained, annealed condition. The values increase slightly with temperature but exhibit sharp minima at $700^{\circ} \mathrm{C}$, similar to data reported by Benz et al. (4) for other Nb-Ti-Al-Cr alloys. Ductility increases sharply beyond $700^{\circ} \mathrm{C}$. The carbon and yttrium addition has no effect on the ductility minimum at $700^{\circ} \mathrm{C}$ but causes a slight, consistent reduction in ductility values on either side of the ductility minimum temperature. This is consistent with the observation of some edge cracking in the cold-rolled sheet of the modified alloy. No edge cracking was observed in the cold-rolled sheets of the base alloy. 


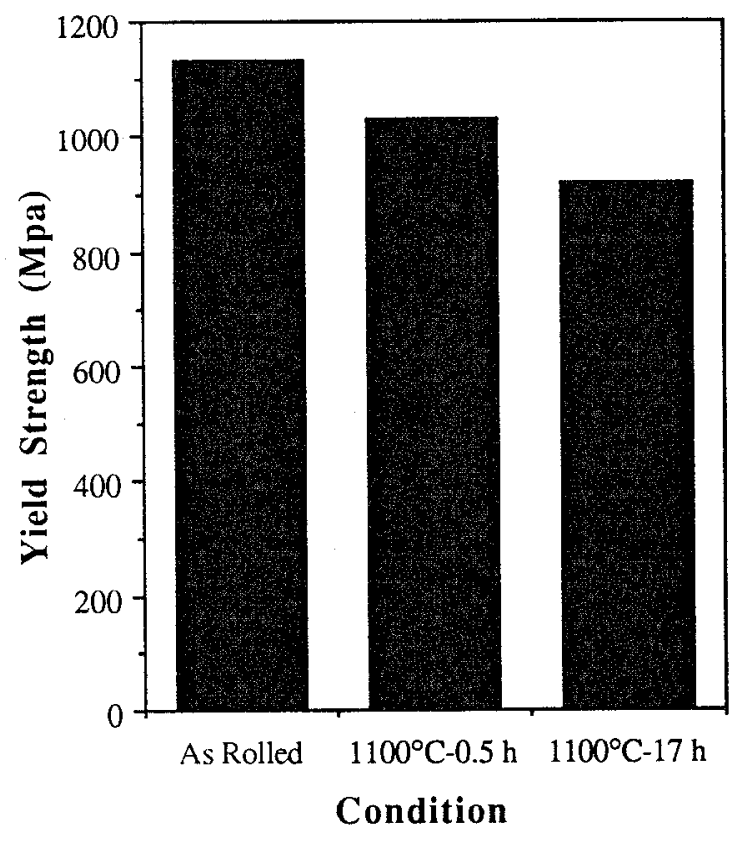

(a)

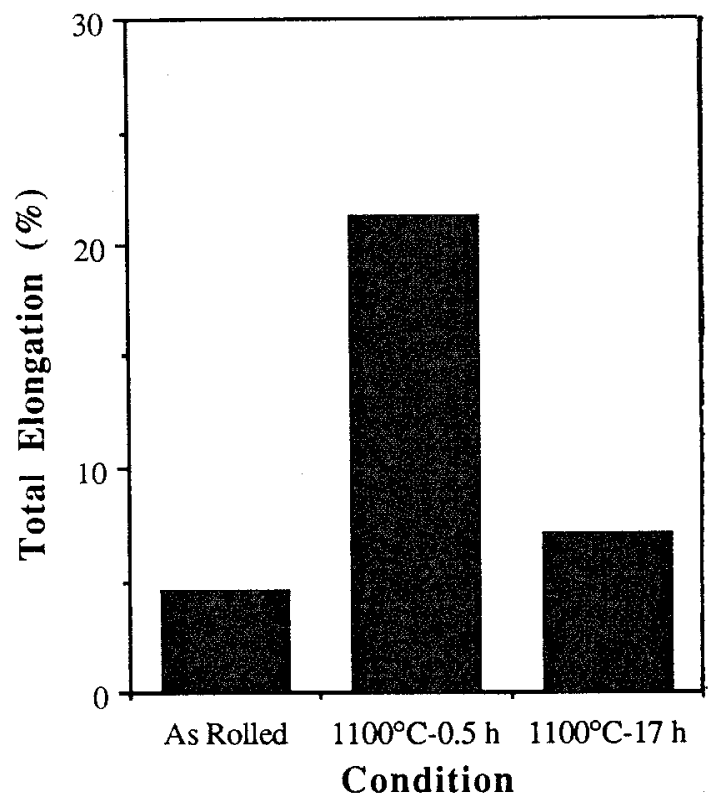

(c)

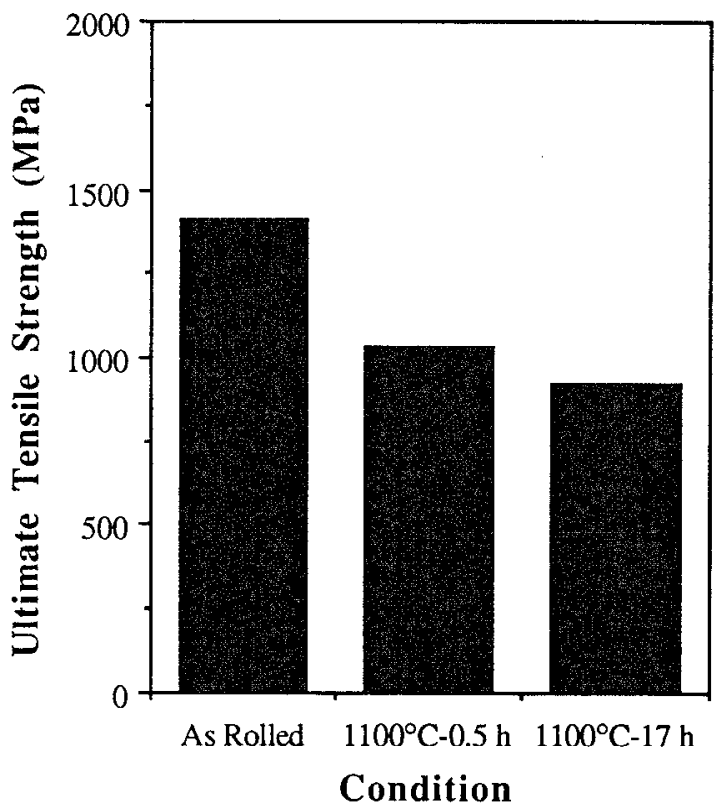

(b)

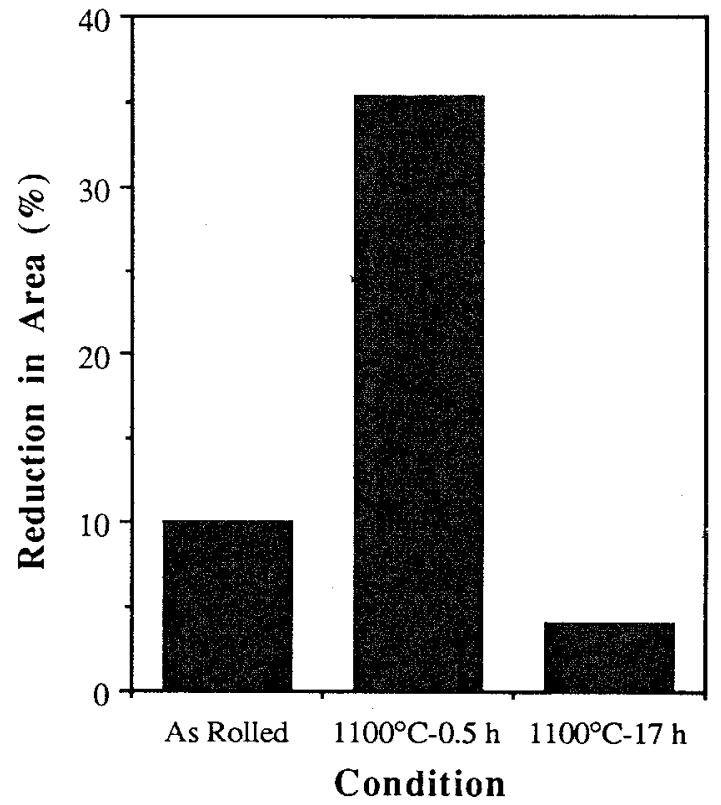

(d)

Figure 1 - Room-temperature tensile properties of the base alloy (Heat 14610) in the as-coldrolled and annealed conditions: (a) yield strength, (b) ultimate tensile strength, (c) total elongation, and $(\mathrm{d})$ reduction of area.

Both the base alloy and the modified alloy exhibited strain softening, characterized by decreasing load past the yield point. The modified alloy also exhibited dynamic strain aging (Portevin-Le Chatelier effect) at a test temperature of $400^{\circ} \mathrm{C}$, presumably from the pinning and unpinning of dislocations at carbon atoms. The creep rupture strength at $650^{\circ} \mathrm{C}$ and $172 \mathrm{MPa}$ of the base alloy is consistent with data reported by Benz et al. (4) on a similar alloy, (Fig. 4). The total elongation and reduction of area values for the base alloy were 8.1 and $3.1 \%$, respectively.

The oxidation response of the alloys used in this study (Fig. 5) is very similar to that of a 39Nb-39Ti-9Al-13Cr alloy reported by Jackson et al. (2), although the measured weight gains for the alloys used in this study seem to be somewhat lower, particularly for the $800^{\circ} \mathrm{C}$ test. 


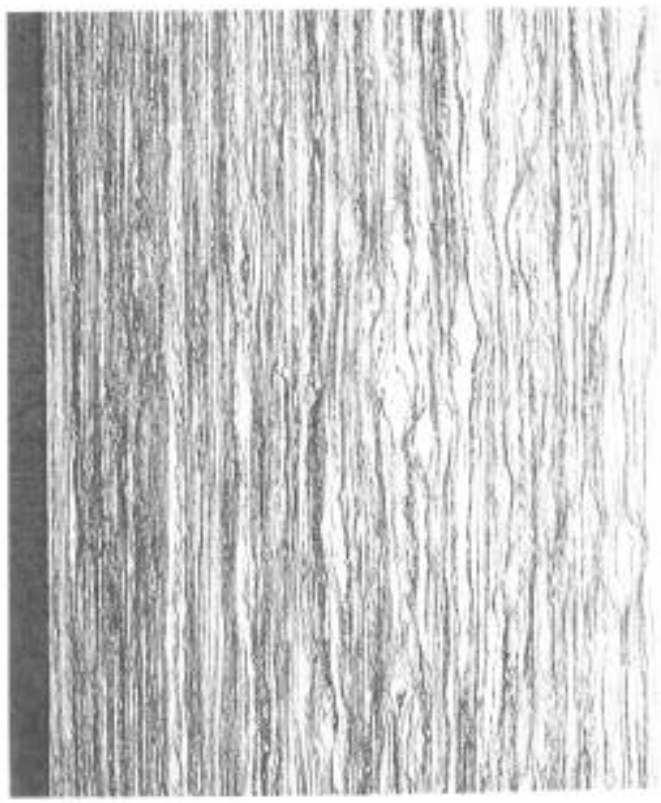

(a)

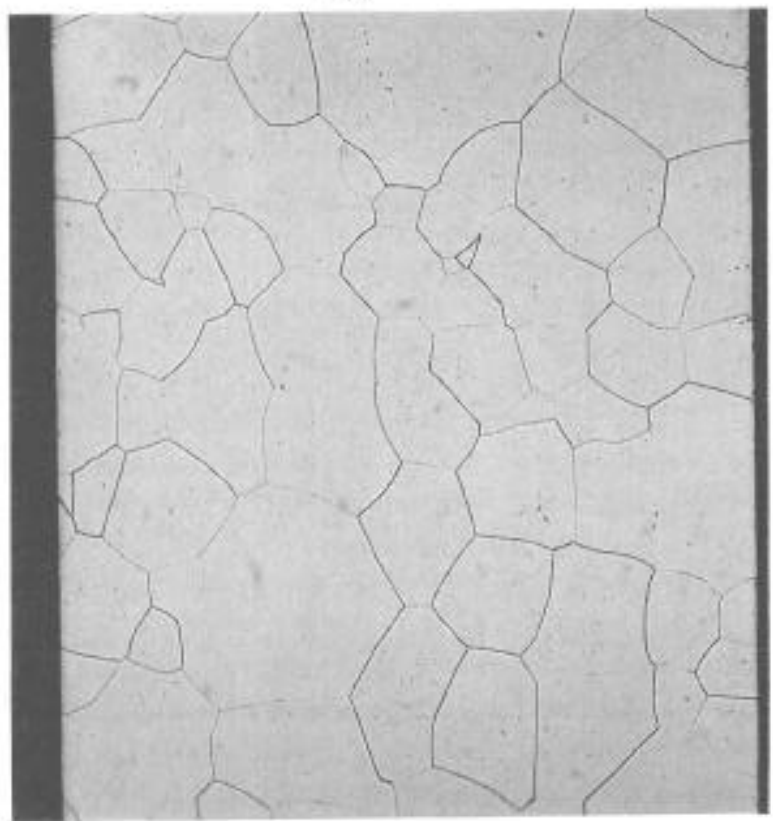

(c)

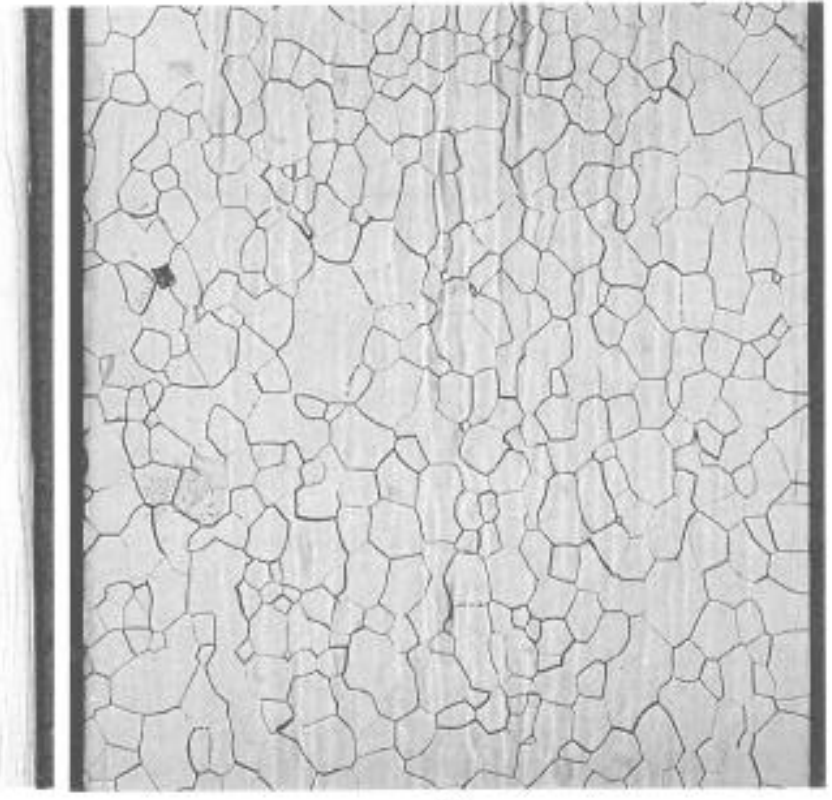

(b)

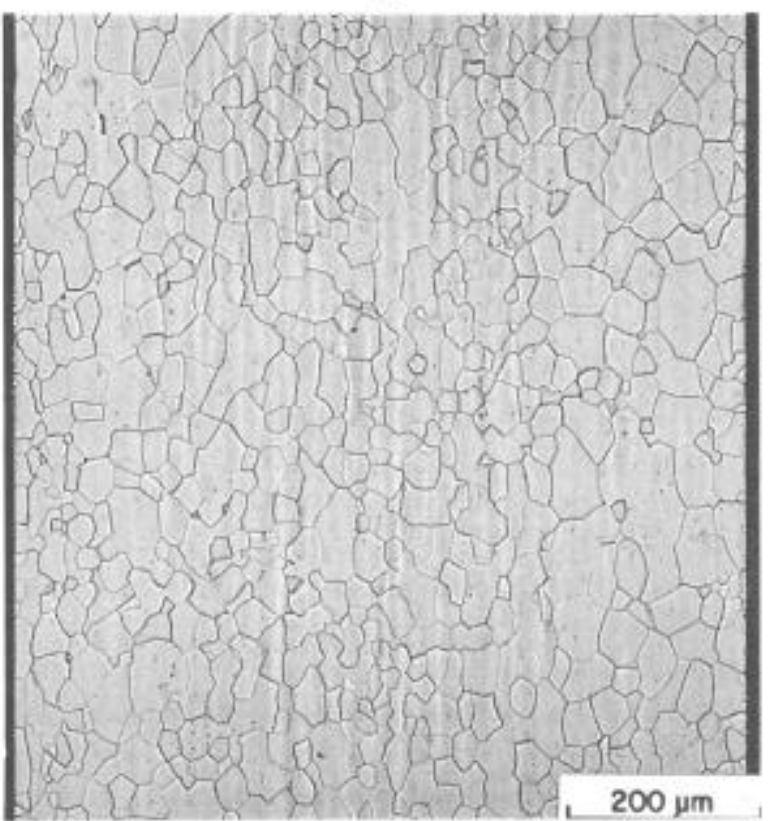

(d)

Figure 2 - Optical micrographs of the base alloy: (a) in the as-cold-rolled condition, (b) after annealing at $1100^{\circ} \mathrm{C}$ for $0.5 \mathrm{~h}$, (c) after annealing at $1100^{\circ} \mathrm{C}$ for $17 \mathrm{~h}$; and (d) optical micrograph of the alloy modified with 0.11 at: \% $\mathrm{C}$ and 0.07 at. $\% \mathrm{Y}$ after annealing at $1100^{\circ} \mathrm{C}$ for $0.5 \mathrm{~h}$.

The oxidation rate at 600 and $700^{\circ} \mathrm{C}$ was low, with no evidence of oxide spallation, even after $500 \mathrm{~h}$ at the test temperature. Tests at temperatures above $800^{\circ} \mathrm{C}$ exhibited spalling and are not included in Fig. 5. The influence of 0.07 at. $\%$ Y on the oxidation resistance was mixed (Fig, 6); weight gains for the modified alloy were lower than that of the base alloy at 600 and $900^{\circ} \mathrm{C}$, and slightly greater than that of the base alloy at 700 and $800^{\circ} \mathrm{C}$. The yttrium addition had no effect on oxide spallation resistance in these tests. 


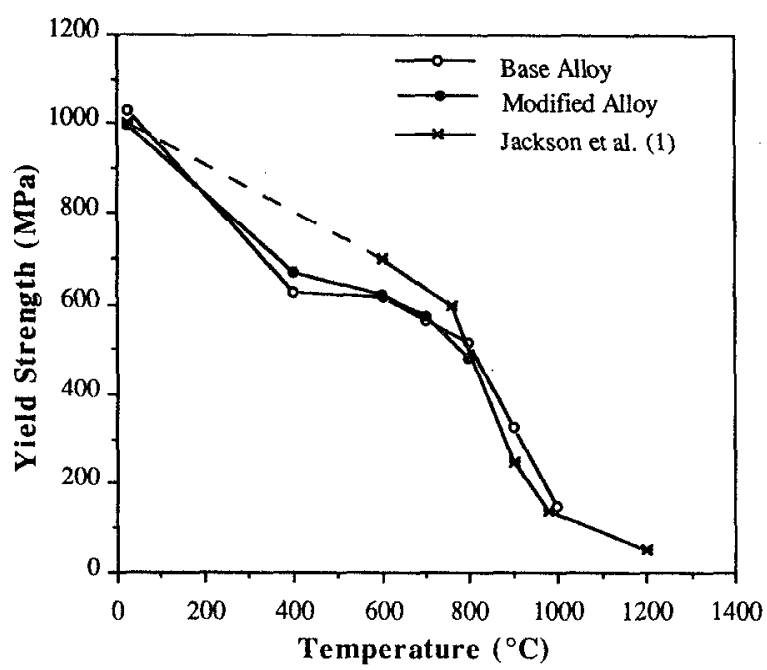

(a)

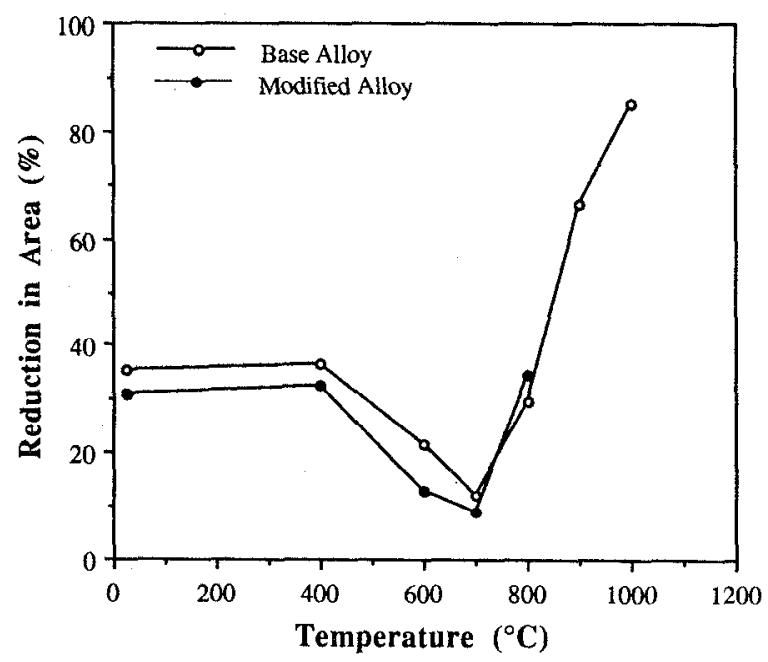

(c)

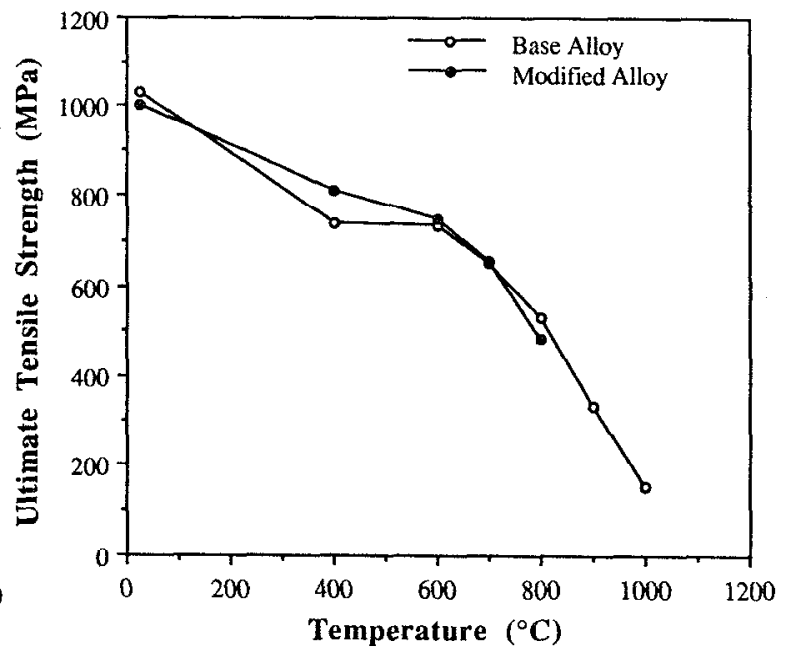

(b)

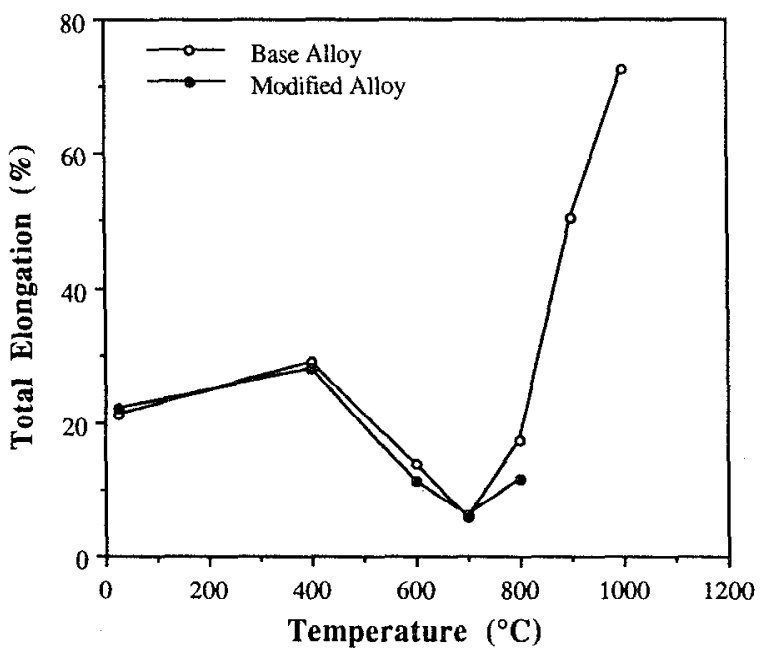

(d)

Figure 3 - Variation of tensile properties with temperature for the base alloy and the alloy modified with 0.11 at. $\% \mathrm{C}$ and 0.07 at. \% Y: (a) yield strength, (b) ultimate tensile strength, (c) total elongation, and (d) reduction of ared.

\section{$\underline{\text { Summary }}$}

The processing characteristics, tensile properties, creep property, and oxidation response of a base alloy of $40 \mathrm{Nb}-40 \mathrm{Ti}-10 \mathrm{Al}-10 \mathrm{Cr}$ and an alloy modified with 0.11 at. $\% \mathrm{C}$ and 0.07 at. \% Y were investigated. Carbon was added for potential strengthening benefits and yttrium was added for a possible improvement in oxidation resistance. The following observations were made:

1. Both the base alloy and the modified alloy were very ductile in the as-cast state and were cold rolled to room temperature without any intermediate annealing treatment.

2. The addition of carbon to the alloy affected its ductility and cold fabricability. The alloy modified with 0.11 at. $\% \mathrm{C}$ and 0.07 at. $\% \mathrm{Y}$ exhibited some edge cracking in the cold-rolled sheet. Alloys with 0.53 at. $\% \mathrm{C}$ could not be cold rolled even after a $1150^{\circ} \mathrm{C}$ annealing treatment and a $50 \%$ hot deformation at $900^{\circ} \mathrm{C}$.

3. Both the base alloy and the modified alloy recrystallized after annealing at $1100^{\circ} \mathrm{C}$ for $0.5 \mathrm{~h}$.

4. Annealing the alloy at $1100^{\circ} \mathrm{C}$ for $17 \mathrm{~h}$ increased the grain size of the base alloy from 43 to $111 \mu \mathrm{m}$. The 0.11 at. $\% \mathrm{C}$ and 0.07 at. $\% \mathrm{Y}$ additions produced a slight refinement in the grain size in specimens annealed at $1100^{\circ} \mathrm{C}$ for $0.5 \mathrm{~h}$, from 43 to $39 \mu \mathrm{m}$. 


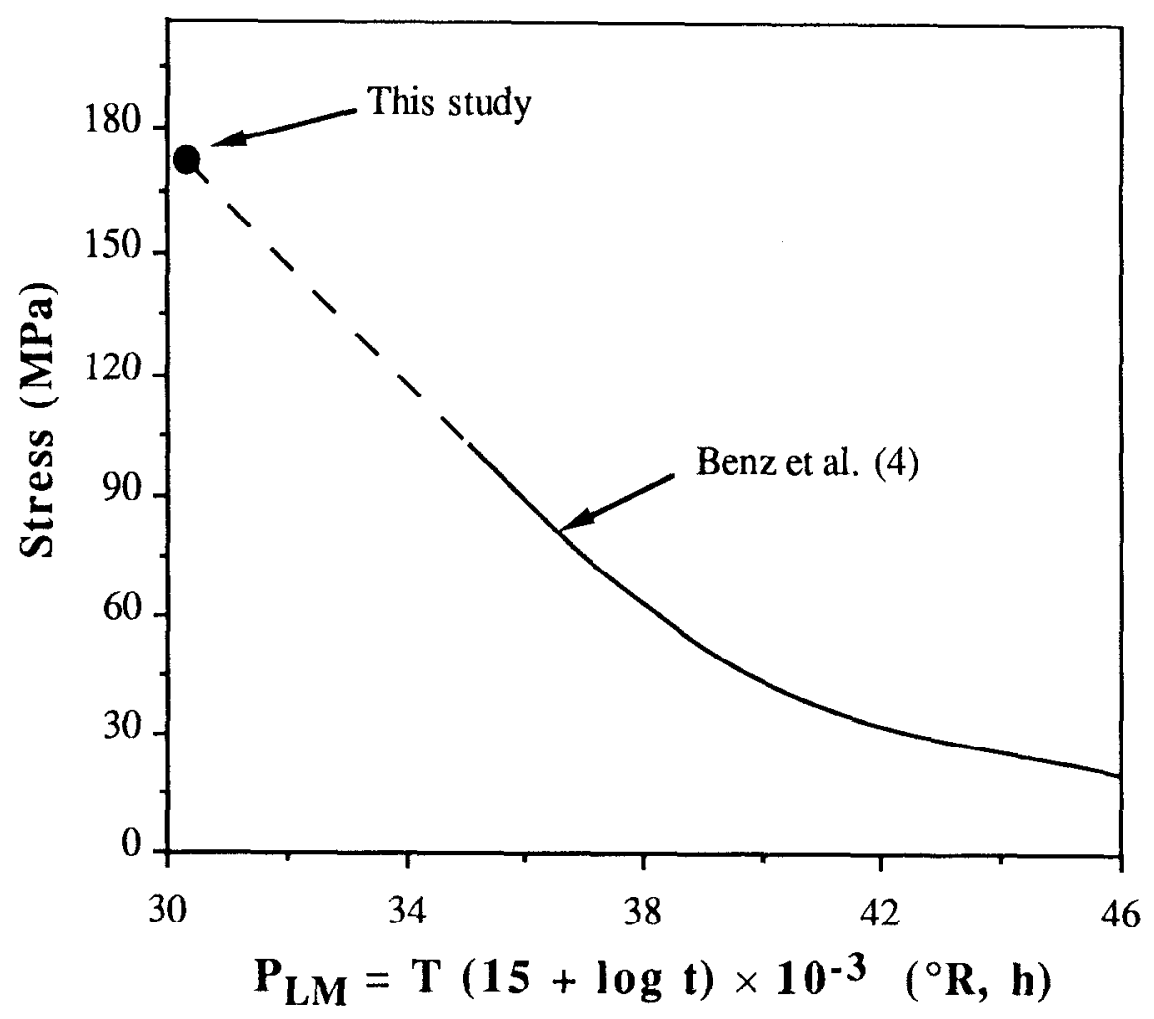

Figure 4 - Larson-Miller plot showing the comparison of creep rupture behavior of the base alloy from this study with data reported in literature (4).

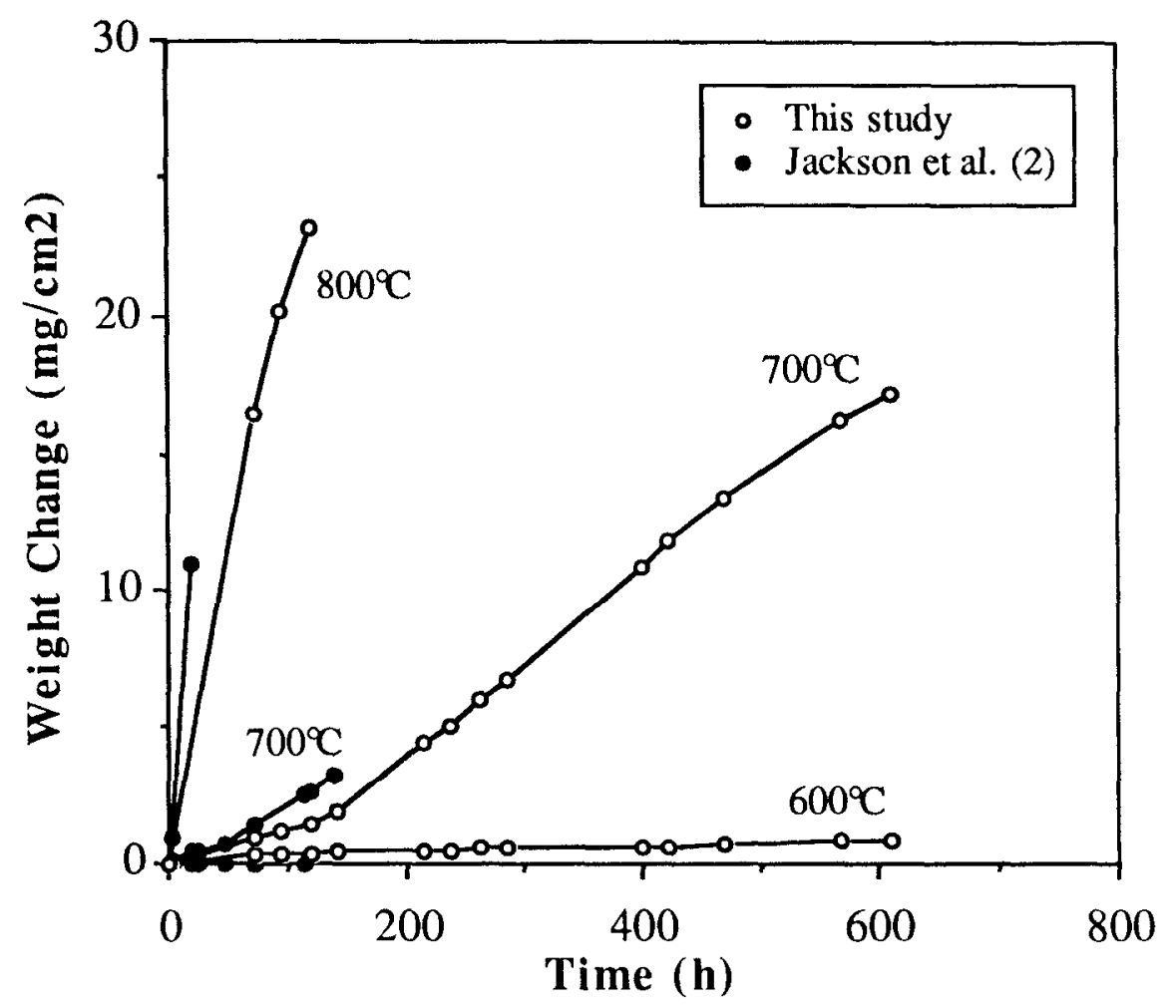

Figure 5 - Oxidation response of the base alloy at 600,700 , and $800^{\circ} \mathrm{C}$. Data from Jackson et al. (2) are included for comparison. 


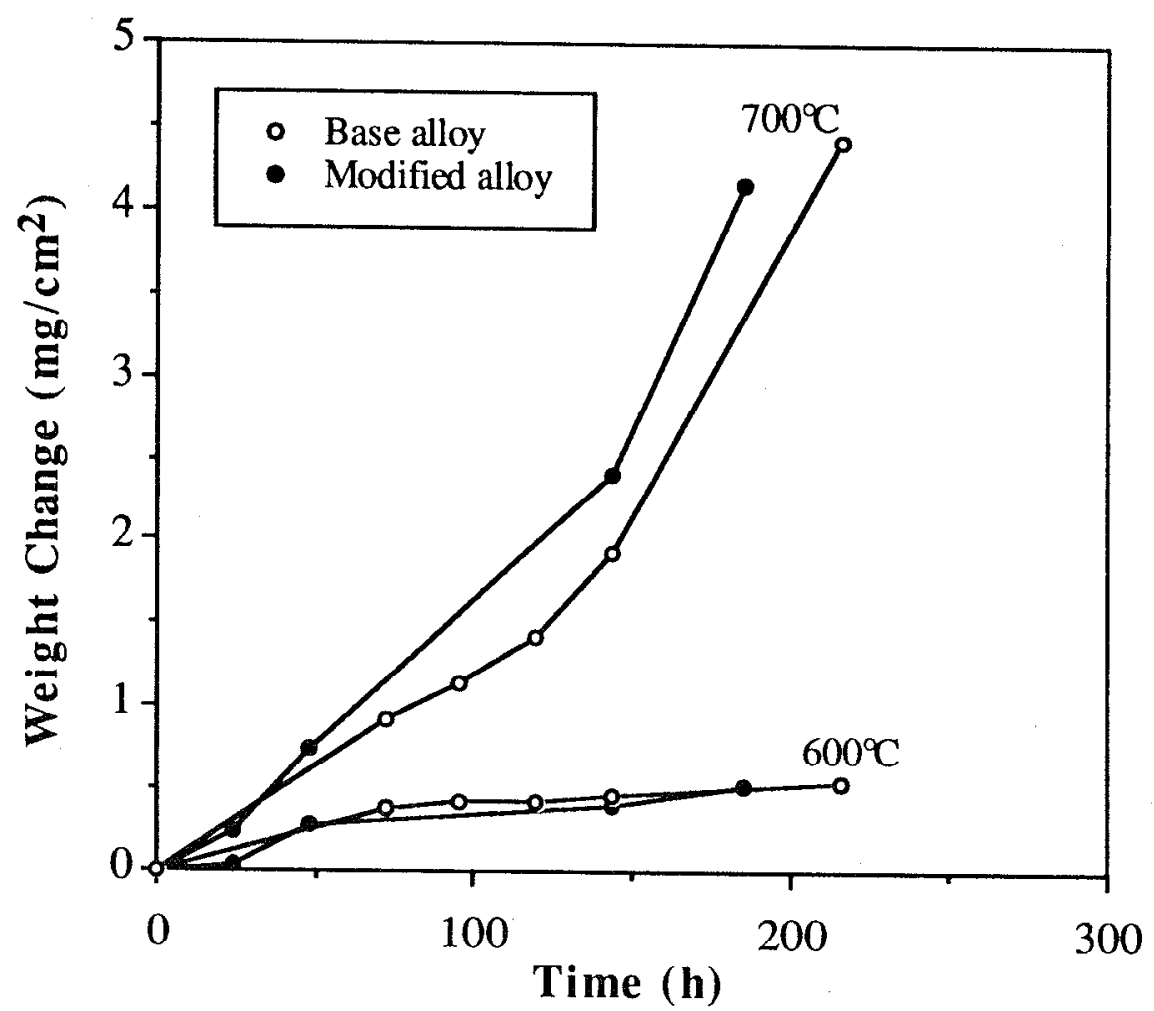

(a)

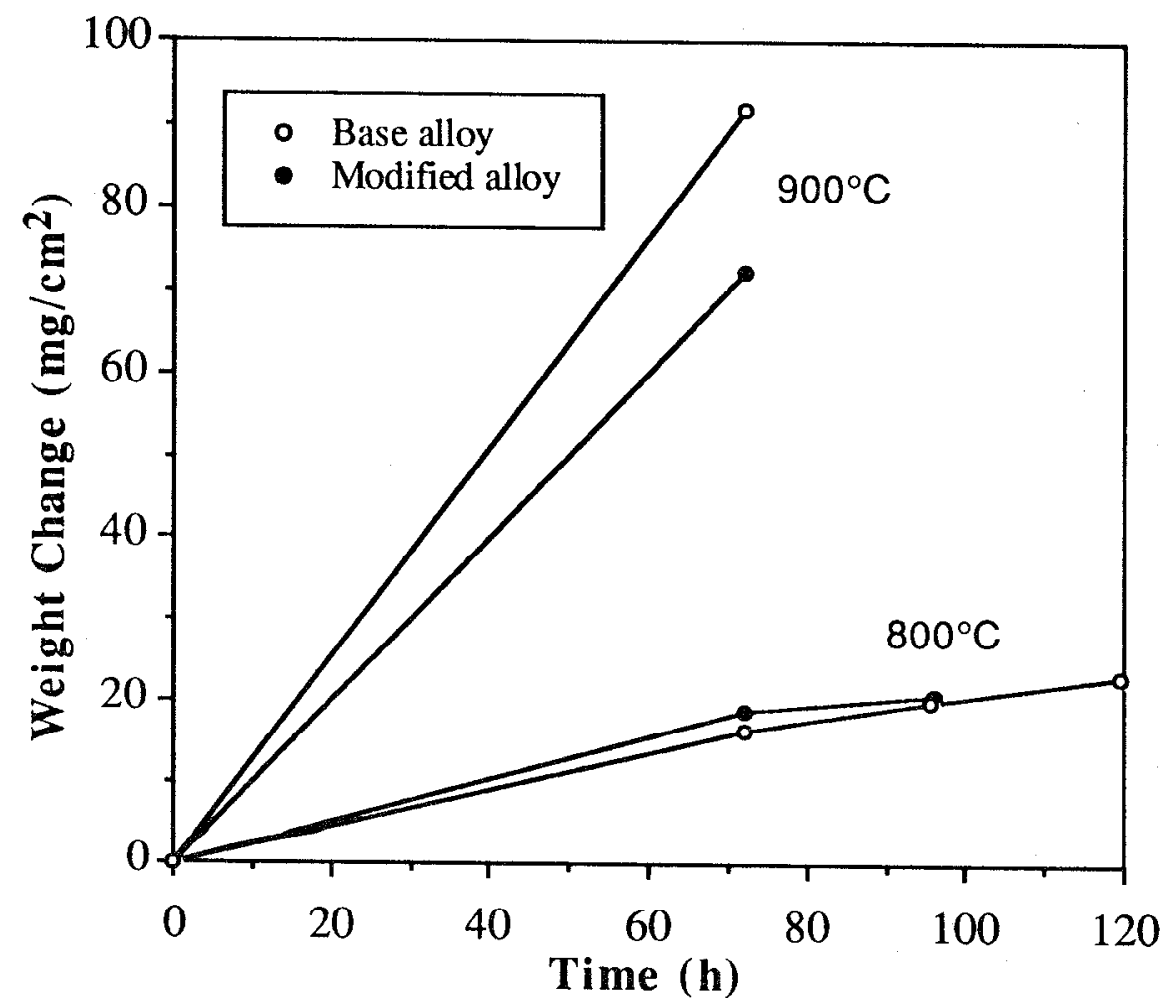

(b)

Figure 6 - Comparison of oxidation response of the base alloy and the alloy modified with 0.11 at. $\% \mathrm{C}$ and 0.07 at. \% Y: (a) 600 and $700^{\circ} \mathrm{C}$ and (b) 800 and $900^{\circ} \mathrm{C}$. 
5. The highest ductility in the base alloy tested at room temperature was obtained in the finegrained, annealed condition. The 17-h annealing treatment reduced both strength and ductility.

6. The variation of yield strength with temperature of the base alloy compared well with values reported for the cast material (1). A ductility minimum was obtained at $700^{\circ} \mathrm{C}$ in both the base alloy and the modified alloy. The addition of carbon and yttrium produced only a small increase in the ultimate tensile strength and corresponding decrease in the reduction of area. Yield strength and tensile elongation were unaffected.

7. Both the base alloy and the modified alloy exhibited strain-softening behavior.

8. The alloy modified with carbon and yttrium exhibited dynamic strain aging at $400^{\circ} \mathrm{C}$.

9. The creep-rupture strength of the base alloy was consistent with data reported in the literature for similar alloys.

10. The oxidation response of the base alloy was similar to that of an alloy reported in the literature (2). The yttrium addition produced a mixed effect on the oxidation behavior of the alloy.

The results of this study and that of others reported in the literature (1-4) suggest that the $40 \mathrm{Nb}-40 \mathrm{Ti}-10 \mathrm{Al}-10 \mathrm{Cr}$ alloy forms a good base alloy suitable for further study in the development of $\mathrm{Nb}$ - $\mathrm{Ti}$ alloys with improved oxidation resistance and high-temperature strength.

\section{Acknowledgements}

The authors thank R. H. Baldwin for tensile and creep tests, C. R. Howell for oxidation tests, T. K. Roche and R. W. Swindeman for reviewing the manuscript, K. Spence for editing, and M. L. Atchley for preparation of the manuscript.

\section{$\underline{\text { References }}$}

1. M. R. Jackson and K. D. Jones, "Mechanical Behavior of Nb-Ti Base Alloys," Refractory Metals: Extraction, Processing and Applications, ed. K. C. Liddell, D. R. Sadoway, and R. G. Bautista (Warrendale, PA: The Minerals, Metals \& Materials Society, 1990), 311-320.

2. M. R. Jackson et al., "Response of Nb-Ti Alloys to High-Temperature Air Exposure," Refractory Metals: Extraction, Processing and Applications, ed. K. C. Liddell, D. R. Sadoway, and R. G. Bautista (Warrendale, PA: The Minerals, Metals \& Materials Society, 1990), 335-346.

3. K. D. Jones et al., "Reaction Layer Structure of Silicide Coatings on Niobium Alloys," Refractory Metals: Extraction, Processing and Applications, ed. K. C. Liddell, D. R. Sadoway, and R. G. Bautista (Warrendale, PA: The Minerals, Metals \& Materials Society, 1990), 299-309.

4. M. G. Benz, M. R. Jackson, and J. R. Hughes, "Composite Strengthening of Nb-Ti Base Alloys," (Report Number 91CRD209, GE Research \& Development Center, October 1991). 